DOI 10.18551/rjoas.2019-05.24

\title{
THE EFFECT OF JOB CRAFTING AGAINST PRODUCTIVE BEHAVIOR
}

\author{
Putri Aldila*, Suhariadi Fendy \\ Faculty of Psychology, University of Airlangga, Surabaya, Indonesia \\ *E-mail: aldilapm946@gmail.com
}

\begin{abstract}
This study aims to know whether there is an influence between job crafting on productive behavior of startup company employees in Indonesia. The sample in this study was carried out on 178 employees who work in Startup Company. The sample consisted of 103 of women and 75 of men. The sampling technique used in this study was random sampling. Data analysis in this study was done using Smart PLS 3.0 program. The results showed that job crafting has a direct and significant influence on productive behavior of startup companies' employee.
\end{abstract}

\section{KEY WORDS}

Employees, Indonesia, startup companies, productivity.

In the current digital era, many business people make changes and adjustments in a modern and dynamic manner with the aim of meeting people's needs. One way to do this is to change the trading system. Business people no longer carry out conventional trading activities, but start trading using digital technology.

Trades by utilizing digital technology, is known as online business. These activities are certainly of interest to many people and even this has become a separate trend because this activity can make it easier for the community to make ends meet. People no longer need to go and look for their needs in certain locations, now people can carry out these activities using digital media even when at home. With the convenience felt by the community, this has an impact on the growth of business startup companies in Indonesia.

Perdani, et al (2018) argued that startups refer to companies that move by using information technology and the internet because they usually operate through websites. The development of startups in Indonesia is classified as very fast in various business fields, such as e-commerce, education, games, lifestyle, science, agribusiness, health, insurance, securities, finance and property. Referring to the startup website in the world, Indonesia ranks 5th in the world with 2,108 business startup companies (starupparking.com). The increasing growth in the number of startups in Indonesia is proportional to the number of failures that hit startup companies.

Perdani et al, (2018) stated that human resources is a factor that affects the growth of business startup companies. Sukandar (2019) employees are often unable to survive and produce maximum performance due to the influence of work and cultural rhythms in the company. Even though the success of startup companies also has a positive impact on the economy in Indonesia. Miroslav (2013) stated that the existence of economic growth and wealth of a country are the result of employee productivity. Productivity can be seen from the perspective of individual employees as indicated by productive behavior. Jex and Britt (2008) explained that productive behavior is the behavior of employees who make a positive contribution to the goals and objectives of the organization.

Suhariadi (2001) explained that there are two factors that can lead to productive behavior of employees at work, namely the existence of environmental factors and individual factors. Furthermore, Suhariadi (2001) explained that environmental factor is a work atmosphere that can affect employees every day in achieving the goals set by the organization which indirectly lead to productive behavior, while individual factor is individual characteristics that appear in the form of mental attitude and contain the meaning of the desires and efforts of individuals who always try to bring out and enhance productive behavior. Some previous studies explained that individual factors that can influence the 
emergence of productive behavior are motivation and intelligence (Suhariadi, 2002; Sumarti, 2012), meaningfulness of life (Herawati and Budiharto, 2010), self-efficacy (Prastia, et al., 2017).

To strengthen the problems in this study, interviews were conducted to get an overview of the problems often faced by employees. Based on the results of interviews conducted with startup company employees, it is known that they are often prosecuted for working on two different roles, must be ready at any time to deal with changes, flexibility related to working hours or job locations, always updated regarding market demand or needs. Thus, employees of business startup companies are expected to be able to make active change efforts that can have a positive impact on work. The change effort is known as job crafting. Tims et al (2012) explained that job crafting is a form of change that employees make on their own initiative to balance demands and resources at work. Wrzesniewski (Dvorak, 2014). argued that job crafting, which is a personal initiative to make changes in his work physically and cognitively involving tasks, relationships at work, and the way individuals think about their work to make it more meaningful.

Ghitulescu (2006) explained that the main characteristic of job crafting is the initiative of employees to change job duties or characteristics, in line with their character or preferences. The initiative is based on personal considerations, namely to elaborate the character of the task or work with oneself and not directly aimed at achieving the organization. Employees who take the initiative to change aspects of their work environment tend to contribute to the effectiveness of the organization. Suhariadi (2001) explained that the process of the emergence of productive behavior is related to the individual's self-condition, which can be interpreted as whether there are seeds in the individual that enable the individual to be energetic and act productively. Leana, Appelbaum and Shevchuk (2009) factors that can influence employees having high performance is job crafting. Lichtenthaler et al (2018) states that employees who have crafting jobs tend to have motivation to work while motivation is a factor in the emergence of productive behavior (Suhariadi, 2002).

Research on job crafting on productive behavior is the first study conducted. But previous research, regarding the variables in this study has been widely carried out but does not connect the two variables directly. In addition, these two variables have not been studied on employees who work for startup companies. Therefore, the researcher was interested in conducting a study of the effect of job crafting on productive behavior of startup company employees.

\section{METHODS OF RESEARCH}

This study used quantitative method in nature of explanatory. Karlinger (2006) explained that the purpose of the study is to explain the causal relationship of a variable through testing the hypothesis. The subjects of this study were employees who work for startup companies in Indonesia. We invited employees to fill out our questionnaires through online-based applications. The sampling technique used in this study was random sampling. The number of samples filling out the questionnaire in this study was 178 employees, on the basis of the consideration that it was not known exactly how many employees in startup companies in Indonesia. The study sample was divided into $103(58 \%)$ women and 75 $(42 \%)$. In addition, the average age of the sample was 28 years $(S D=3.49)$.

The measurement in this study used productive behavior questionnaire belonging to Suhariadi (2001), the measuring instrument consisted of 14 items $(\alpha=0.670)$ and measured the dimensions of effective behavior and efficient behavior. This study used Job Crafting Scale compiled from the dimensions of task crafting, relational crafting, and cognitive crafting (Berg, Dutton, and Wrzeniewski, 2013) with a valid number of items $24(\alpha=0.918)$. In this study, data analysis used inferential data analysis technique. The use of inferential data analysis techniques was to test hypotheses using Smart Partial Least Square 3.0. Hair, et al (2012) explained that the use of SEM-PLS aims to predict and develop theories, besides that the use of SEM-PLS has the advantage that the sample used does not have to be a large number. 


\section{RESULTS AND DISCUSSION}

Data analysis technique used to test hypotheses was analytical techniques using Smart PLS. The use of this analysis technique was adjusted to the purpose of the study which aimed to know the direct influence of the independent variable on the dependent variable.

Table 1 - Results of analysis

\begin{tabular}{|c|c|c|c|}
\hline $\mathrm{n} / \mathrm{n}$ & Coefficient Path & T-Statistics & Information \\
\hline Job Crafting $\rightarrow$ Productive Behavior & 0.688 & 11.407 & Positive and Significant \\
\hline
\end{tabular}

The findings are shown in table 1 indicates result of the estimation results of the direct influence of job crafting on productive behavior is known to be 0.688 with a t-statistic value of 11.407 greater than the t-count value $>1.96$ which indicates that there is a significant positive influence between job crafting and productive behavior. This means that an increase in job crafting will result in an increase in productive behavior, and vice versa if the decline in job crafting will result in a decrease in productive behavior.

Based on the results of this study, employees with job crafting will make changes in work with the aim of getting better results. Tims, et al. (2012) job crafting can be realized in the efforts of employees in maximizing work resources, using relationships and attracting benefits from relations to work, reducing things that can burden work and the readiness of employees to accept new work challenges. These efforts can be realized because, employees are able to direct the energy they have to change the characteristics of a job in order to achieve a goal and value considered more beneficial (Tims et al, 2015).

Suhariadi (2001) employees with productive behavior will pay attention and consider the effectiveness and efficiency in achieving organizational goals. Gilmore (1974) a productive person will emphasize a positive contribution to his environment where he resides. With the existence of constructive, imaginative, and creative actions from individuals within an organization, it is expected to increase productivity. Productive individuals describe the potential, perception and creativity of someone who always wants to contribute the ability to benefit themselves and their environment.

\section{CONCLUSION}

Based on the results of the study it can be concluded that Job crafting has a positive and significant influence on productive behavior. The results of the study show that $100 \%$ of the sample is millennial generation employees. Therefore organizations need to provide opportunities for employees to be able to make their own decisions in doing work. This can give employees the opportunity to use the skills employees have at work.

\section{REFERENCES}

1. Berg, J.M., Dutton, J.E., and Wrzesniewski, A. 2013. Job Crafting and meaningful work. In B. J. Dik, Z.S. Byrne and M. F. Steger (Eds.), Purpose and meaning in the workplace. Washington, DC: American Psychological Association.

2. Dvorak, K., J. (2014). The theoretical development and empirical testing of the measure of job crafting (MJC). Thesis Colorado State University.

3. Ghitulescu, B.E. 2006. Shaping tasks and relationships at work: examining the antecedents and consequences of employee job crafting dissertation. University of Pittsburgh.

4. Gilmore, H.L. (1974). The Productive Personality. https://www.researchgate. net/publication/31634550_The_Productive_Personality_JV_Gilmore.

5. Hair, J.F., Ringle, C.M., and Sarstedt, $\bar{M}$. 2012. Partial Least Squares: The Better Approach to Structural Equation Modeling?. Long Range Planning, 45 (5-6), 312-319. 
6. Herawati, Ermy., and Budiharto, Sus. 2010. Hubungan Antara Kebermaknaan Hidup Dengan Perilaku Produktif Pada Guru SLB. https://philpapers.org/ rec/HERHAK.

7. Jex, S. M. \& Britt, T. W. 2008. Organizational Psychology A Scientist Practioner Approach (Second Edition). New Jersey: John Wiley \& Sons, Inc.

8. Kerlinger, Fred. N. 2006. Foundation of Behavioral Research (3nd ed,). Yogyakarta: Gadjah Mada University Press.

9. Leana, C., Appelbaum, E., and Shevxhuk, I. 2009. Work process and quality of care in early childhood education: The role of job crafting. Academy of Management Journal, 52, 1169-1192.

10. Lichtenthaler, Philipp. W., and Fischbach, Andrea. 2018. Leadership, job crafting, and employee health and performance. Leadership \& Organization Development Journal. https://doi.org/10.1108/LODJ-07-2017-0191

11. Miroslav, D and Ribraric,H.M. 2013. Labour Productivity Model For The Hotel Industry. Ekonomski Pregled, 64 (4) 351-375 (2013).

12. Perdani, M.D.K., Widyawan., Santoso., and Paulus Insap. 2018. Faktor-Faktor Yang Mempengaruhi Pertumbuhan Startup Di Yogyakarta. Seminar Nasional Teknologi Informasi dan Komunikasi 2018 (SENTIKA 2018) ISSN: 2089-9815.

13. Prastia, R, Mintarti, S.M., and Wardoyo, C. 2017. Faktor-Faktor Yang Memengaruhi Perilaku Produktif Mahasiswa Fakultas Ekonomi Angkatan Tahun 2013. Journal of Education, 2 (2), 238-245. http://journal.um.ac.id/index.php/jptpp/article/view/8537.

14. Suhariadi, Fendy. 2001. Produktivitas sebagai Bentuk Perilaku. Insan Media Psikologi, 3 (3), 119-137.

15. Suhariadi, Fendy. 2002. Pengaruh Inteligensi dan Motivasi Terhadap Semangat Penyempurnaan Dalam Membentuk Perilaku Produktif Efisien. Jurnal Anima, 17.

16. Sunandar, Clara. 2019. Startup Teknologi Sering Kehilangan Karyawan Karena Alasan Ini. https://www.wartaekonomi.co.id/read212851/startup-teknologi-sering-kehilangankaryawan-karena-alasan-ini.html. Accessed on 3-16-2019.

17. Tims, M., Bakker, A.B., and Derks, D. 2012. Development and validation of the job crafting scale. Journal of Vocational Behavior, 80, 173-186.

18. Tims, M., Bakker, A.B., and Derks, D. 2015. Job crafting and job performance: A longitudinal study. European Journal of Work and Organizational Psychology, 24 (6), 914-928. 